\title{
Levels of Complement Regulatory Molecules in Lung Cancer: Disappearance of the D17 Epitope of CD55 in Small-cell Carcinoma
}

\author{
Takahiko Sakuma, ${ }^{1}$ Ken Kodama,${ }^{2}$ Tomoko Hara, ${ }^{3}$ Yoshimi Eshita, ${ }^{4}$ Nobuhiko Shibata, ${ }^{4}$ \\ Misako Matsumoto, ${ }^{3}$ Tsukasa Seya ${ }^{3,6}$ and Yoichi Mori ${ }^{5}$ \\ ${ }^{I}$ Fourth Department of Internal Medicine, ${ }^{2}$ Second Department of Surgery, ${ }^{3}$ Department of Immu- \\ nology, ${ }^{4}$ First Department of Internal Medicine and ${ }^{5}$ Department of Cell Biology, Center for Adult \\ Diseases, Osaka, 1-3-3 Nakamichi, Higashinari-ku, Osaka 537
}

\begin{abstract}
The levels of complement-regulatory molecules (complement receptor type one [CR1], decayaccelerating factor [DAF], membrane cofactor protein [MCP], and an inhibitor of membrane attack complex [CD59]) in lung cancer cells were analyzed to investigate the relation between their expression and histological subtypes, and the possibility of homologous complement deposition on cancer cells. In 25 cell lines (10 adenocarcinoma, 3 large-cell carcinoma, 7 small-cell lung cancer [SCLC], and 5 squamous cell carcinoma), flow cytometric analysis revealed that MCP was expressed in all cell lines, whereas none of the cell lines was CR1-positive. CD59 was detected in all cells. The DAF epitope defined by IA10 was expressed in all cells except one large cell carcinoma cell line. However, another epitope for anti-DAF monoclonal antibody, D17, was not detected in $5(71.4 \%)$ SCLC and in $4(22.2 \%)$ non-small-cell lung cancer. This disparity was seen in most cell lines, irrespective of histological subtypes. The loss of $\mathrm{D17}$ reactivity seemed to be pertinent to malignant phenotype, because most of the normal pulmonary cells possessed the D17 epitope. Furthermore, a cell line lacking DAF (IA10-/D17 ${ }^{-}$) allowed alternative pathway-mediated homologous complement (C3) deposition after pretreatment with anti-MCP antibody. This raises a new possibility for immunotargeting of cancer. These cell lines should be useful in studying the biology of lung cancer.
\end{abstract}

Key words: Decay-accelerating factor (DAF, CD55) - Flow cytometry - Lung cancer Monoclonal antibody

Lung cancer is the leading cause of cancer death in the United States and in some Western countries. ${ }^{1,2)}$ Lung cancer is clinically divided into $\mathrm{SCLC}^{7}$ and NSCLC. SCLC is a highly malignant tumor that grows rapidly and disseminates widely, and is treated with chemotherapy and/or radiation. ${ }^{3)}$ NSCLC, which is usually not chemo- or radiosensitive, is best treated with surgical resection. ${ }^{4)}$ Besides these differences in clinical behavior, SCLC shows neuroendocrine properties, such as the presence of neurosecretory dense core granules, ${ }^{5)}$ secretion of multiple hormones/peptides, andthe expression of neural-type isozymes. ${ }^{6}$ ) Some of them are available as tumor markers of SCLC. ${ }^{7)}$ Recently, DAF, one of the complement-regulators, has been reported to be absent from SCLC. ${ }^{8)}$ This fact indicates that complement-regulatory molecules may be novel tumor markers of SCLC.

\footnotetext{
${ }^{1}$ Present address: Department of Internal Medicine III, Osaka University Medical School, Fukushima-ku, Osaka 553.

${ }^{6}$ To whom correspondence should be addressed.

${ }^{7}$ Abbreviations: SCLC, small-cell lung cancer; CR1, complement receptor type one (C3b/C4b receptor, CD35); DAF, decay-accelerating factor (CD55); $\mathrm{mAb}$, monoclonal antibody; MAC, membrane attack complex that is formed by C5b-9; MCP, membrane cofactor protein (CD46); NSCLC, non-small-cell lung cancer (adeno-, squamous, and large cell carcinomas); CD59, an inhibitor of MAC formation.
}

Not only foreign organisms but also host cells are continuously exposed to autologous complement system. Uncontrolled activation of the complement could result in formation of MAC on self tissues and activation of $\mathrm{C} 3$ receptor-positive host effector cells, in addition to generation of inflammatory mediators. However, host cells can avoid complement attack because they are endowed with complement-regulatory molecules: CR1 facilitates dissociation of classical and alternative pathway $\mathrm{C} 3$ convertases, and acts as a cofactor for Factor I-mediated cleavage of $\mathrm{C} 3 \mathrm{~b}$ and $\mathrm{C} 4 \mathrm{~b}^{9}$; DAF accelerates dissociation of classical and alternative pathway $\mathrm{C} 3$ convertases, $\mathrm{C} 4 \mathrm{~b} 2 \mathrm{a}$ and $\mathrm{C} 3 \mathrm{bBb}$ complex ${ }^{10)}$; MCP serves as a cofactor for Factor I-mediated cleavage of $\mathrm{C} 3 \mathrm{~b}$ and $\mathrm{C}_{4} \mathrm{~b}^{11)}$; and CD59 blocks $\mathrm{C} 9$ binding to $\mathrm{C} 5 \mathrm{~b}-8$ to prevent formation of MAC. ${ }^{12,13)}$ DAF, MCP and CD59 thus serve as safeguards against autologous complement attack. Cancer cells, during the processes of invasion and metastasis, are also exposed to complement in blood. If the complementregulators are insufficiently expressed or functionally impaired in cancer cells, the cells can be selectively damaged by complement.

With $\mathrm{mAbs}$ raised against these complement-regulators, we evaluated the expression of these molecules in lung cancer cell lines, both SCLC and NSCLC, and found that DAF was present in almost all cell lines. 
However, another anti-DAF mAb we newly obtained gave different results, especially in SCLC. The results may imply the expression of structurally altered DAF molecules in the tumor cells.

Homologous C3 deposition on cancer cells due to blocking of MCP was anticipated if DAF were deficient, since all the cells lacked CR1. We found this was the case. These results raise a new possibility for immunological targeting of cancer cells.

\section{MATERIALS AND METHODS}

Cell lines Seventeen cell lines were established from patients with histologically and cytologically proven primary lung cancer (Table I). Pleural effusions were obtained aseptically and heparinized, and cancer cells were collected by gradient centrifugation or centrifugation after hemolysis. Solid tumors were finely minced with a scalpel and plated into culture vessels.

Lu24 was grown in serum-free medium (SFM 101, Nissui Pharmaceutical Co., Tokyo) at $37^{\circ} \mathrm{C}$, under a $5 \%$ $\mathrm{CO}_{2}$ humidified atmosphere. Adherent cells were cultured in Eagle's minimum essential medium (Nissui Pharmaceutical Co.) containing kanamycin and $10 \%$ heat-inactivated fetal calf serum (FCS). For other cells, RPMI-1640 (GIBCO Lab., Grand Island, NY) medium

Table I. Profiles of Cell Lines Established

\begin{tabular}{lcccc}
\hline Cell line & Histology & Origin & $\begin{array}{c}\text { Growth } \\
\text { behavior }\end{array}$ & $\begin{array}{c}\text { Tumorigenicity } \\
\text { in nude mice }\end{array}$ \\
\hline CADO LC1 & LG $^{a)}$ & BR $^{b)}$ & Mono & + \\
CADO LC3 & LG & LN & Mono & + \\
CADO LC5 & AD & PF & Mono & - \\
CADO LC6 & SM & PF & Susp & + \\
CADO LC7 & AD & PF & Mono & - \\
CADO LC8 & SM & HE & Susp & + \\
CADO LC9 & AD & PF & Susp & + \\
CADO LC10 & AD & PF & Mono & + \\
CADO LC11 & AD & PF & Mono & + \\
CADO LC15 & SQ & BR & Mono & ND \\
CADO LC17 & SM & LN & Susp & + \\
CADO LC20 & AD & PF & Sphe & + \\
CADO LC21 & AD & PF & Susp & + \\
CADO LC22 & SM & PR & Susp & + \\
CADO LC24 & LG & PF & Mono & ND \\
CADO LC26 & AD & PF & Mono & + \\
CADO LC41 & AD & PF & Mono & ND \\
\hline
\end{tabular}

a) $\mathrm{AD}$, adenocarcinoma; LG, large cell carcinoma; SM, small-cell carcinoma; SQ, squamous cell carcinoma.

b) BR, brain metastasis; HE, hepatic metastasis; LN, lymph node metastasis; PF, pleural effusion; PR, primary tumor.

c) Mono, monolayer; Sphe, spheroid; Susp, suspension.

d) ND, not determined. supplemented with $10 \%$ FCS, streptomycin and penicillin $\mathrm{G}$ was used. Lu24 and Lu134A cells ${ }^{14)}$ were kindly supplied by Dr. T. Terasaki (National Cancer Center, Tokyo). Four cell lines of squamous cell carcinoma of the lung (EBC-1, LC-1 sq, LK-2, and VMRC-LCP), and two cell lines of SCLC (SBC5 and RERF) were obtained from the Japanese Cancer Research Resources Bank (Tokyo). Tumorigenicity was determined by inoculating cancer cells into nude mice subcutaneously.

Monoclonal antibodies Preparation of the mAbs against MCP (M177), ${ }^{15,16)}$ CR1 (31R) ${ }^{16)}$ and DAF (D17) ${ }^{17)}$ has been described elsewhere. Another anti-DAF (IA10) ${ }^{18}$ and anti-CD59 $(5 \mathrm{H} 8)^{19)} \mathrm{mAbs}$ were generous gifts from Dr. T. Kinoshita (Institute for Microbial Diseases, Osaka University) and Dr. M. Tomita (Showa University, Tokyo), respectively.

Analysis of complement-regulatory molecules in cancer cells Carcinoma cells were harvested by centrifugation (suspension culture) or trypsinization $(0.25 \%$ trypsin for $10 \mathrm{~min}$; monolayer). Spheroids were disaggregated with trypsin. Trypsin treatment does not affect DAF, ${ }^{20)}$ MCP, ${ }^{21)}$ or CD59 $9^{19)}$ molecules. Although CR1 is labile to proteolysis, ${ }^{22)}$ our trypsinization conditions did not abrogate CR1 of granulocytes (data not shown). Cancer cells $\left(10^{6}\right.$ cells suspended in $100 \mu 1$ of Dulbecco's modified phosphate-buffered saline containing bovine serum albu$\min [0.5 \% \mathrm{w} / \mathrm{v}])$ were incubated with $10 \mu \mathrm{g}$ of $\mathrm{mAbs}$ for $45 \mathrm{~min}$ on ice with $50 \mu \mathrm{l}$ of human plasma containing 10 $\mathrm{m} M$ EDTA. Murine non-immune IgG (Sigma Chemicals, St. Louis, MO) was used as a negative control. The cells were washed twice and incubated with $5 \mu \mathrm{g}$ of fluorescein isothiocyanate (FITC)-conjugated caprine anti-mouse IgG (Cappel, Organon Teknika Corp., West Chester, PA) for $45 \mathrm{~min}$ on ice. The cells were rinsed twice, then fixed with $0.5 \%(\mathrm{w} / \mathrm{v})$ paraformaldehyde. ${ }^{16)}$ The samples were analyzed with an EPICS Profile II (Coulter Electronics, Hialeah, FL) within a week.

Mean fluorescent shift (MFS) was calculated by subtracting the values of mean peak channel of controls from those of the corresponding samples. MFS greater than 1.0, which is the minimal significant shift on Profile II, was defined as positive expression. Each sample was assayed at least twice independently, and the mean MFS value was adopted.

Immunohistochemical analysis of complement regulators in normal lung Normal pulmonary tissues were obtained from an autopsy case of non-malignant disease. The excised lungs were fixed with acetone. Endogenous peroxidase activity was blocked with $2 \% \mathrm{H}_{2} \mathrm{O}_{2}$ for 10 min. The specimens were reacted with primary antibodies diluted 50-200 fold for $1 \mathrm{~h}$ at room temperature. Color was developed with HRP-labeled anti-mouse IgG (Cappel) and 3,3'-diaminobenzidine (Wako Pure Chemical Industries, Ltd., Osaka; $1 \mathrm{mg} / \mathrm{ml}){ }^{23)}$ 
Analysis of C3 deposition on cancer cells To test if the lack of D17 epitope was associated with homologous C3 deposition, we treated three types of cells, $\mathrm{IA} 10^{+} / \mathrm{D} 17^{+}$, $\mathrm{IA} 10^{+} / \mathrm{D} 17^{-}$, and $\mathrm{IA} 10^{-} / \mathrm{D} 17^{-}$, with anti-MCP $\mathrm{mAb}$ and then $\mathrm{Mg}$-ethyleneglycol-bis ( $\beta$-aminoethyl ether)$\mathrm{N}, \mathrm{N}, \mathrm{N}^{\prime}, \mathrm{N}^{\prime}$-tetraacetic acid (EGTA)-serum (capable of activating the alternative pathway). ${ }^{24)}$ The cancer cells $\left(1-2 \times 10^{6}\right)$ were pretreated with M177 for $45 \mathrm{~min}$ at room temperature, then incubated with $50 \mu \mathrm{l}$ of human serum containing $10 \mathrm{mM}$ EGTA and $2 \mathrm{mM} \mathrm{MgCl}$, and $150 \mu 1$ of EGTA-GVB (gelatin veronal buffer; barbital 25 $\mathrm{m} M, \mathrm{NaCl} 0.15 M$, EGTA $10 \mathrm{~m} M, \mathrm{MgCl}_{2} 2 \mathrm{~m} M$, gelatin $0.5 \%[\mathrm{w} / \mathrm{v}])$ for $1 \mathrm{~h}$ at $37^{\circ} \mathrm{C}$. For a control, human serum supplemented with $10 \mathrm{mM}$ EDTA and $150 \mu \mathrm{l}$ of EDTA-GVB (barbital $25 \mathrm{~m} M$, NaCl $0.15 M$, EDTA 10 $\mathrm{m} M$, gelatin $0.5 \%[\mathrm{w} / \mathrm{v}])$ was employed. The cells were stained in the same way as in the assay of complementregulatory molecules except that leporine anti-humanC3c (Behring, Marburg, Germany) and FITC-conjugated caprine anti-rabbit IgG (Cappel) were used.

\section{RESULTS}

Cell lines The characteristics of the cell lines established are listed in Table I. SCLC cell lines (CADO LC6, LC8, and LC22) grew as tightly packed floating aggregates, as did LU24 and LU134A. Three adenocarcinoma lines (CADO LC9, LC17 and LC21) expanded in loosely aggregated cell clusters when cultured in plain dishes. One adenocarcinoma (CADO LC20) proliferated as spheroids that had a central cavity. Other adenocarcinoma, squamous cell carcinoma, and large-cell carcinoma cells multiplied as monolayers.

Complement-regulatory molecules in lung cancer cells The flow cytometric analysis of complement-regulators is shown in Table II. Whereas MCP was ubiquitously present in all cell lines, CR1 was not detected in any of the cells. CD59 was found in all cells tested. Unexpectedly, almost all cells expressed the IA 10 epitope except CADO LC3. We therefore used another anti-DAF mAb (D17) and found that five $(71.4 \%)$ SCLC and four $(22.2 \%)$

Table II. Expression of Complement-regulatory Molecules

\begin{tabular}{|c|c|c|c|c|c|}
\hline \multirow{2}{*}{ Cell line } & \multicolumn{5}{|c|}{ Mean fluorescence shift } \\
\hline & $\mathrm{MCP}$ & CR1 & DAF(D17) & DAF(IA10) & $\overline{\mathrm{CD} 59}$ \\
\hline \multicolumn{6}{|c|}{ Small cell carcinoma } \\
\hline CADO LC6 & 6.72 & 0.363 & 0.845 & 25.3 & 35.7 \\
\hline CADO LC8 & 12.1 & $\sim 0$ & $\sim 0$ & 1.67 & 24.2 \\
\hline CADO LC22 & 13.5 & $\sim 0$ & 4.38 & 34.9 & 1.53 \\
\hline LU24 & 12.1 & $\sim 0$ & $\sim 0$ & 25.4 & 34.3 \\
\hline LU134A & 6.62 & 0.108 & 0.548 & 1.67 & 19.9 \\
\hline SBC5 & 7.30 & $\mathrm{ND}^{a)}$ & $\sim 0$ & 0.773 & ND \\
\hline RERF & 30.3 & ND & 12.6 & 23.4 & ND \\
\hline \multicolumn{6}{|l|}{ Adenocarcinoma } \\
\hline CADO LC5 & 35.0 & $\sim 0$ & 0.517 & 3.60 & 35.0 \\
\hline CADO LC7 & 35.0 & $\sim 0$ & 14.5 & 38.6 & 49.8 \\
\hline CADO LC9 & 26.2 & $\sim 0$ & 0.300 & 27.0 & 175 \\
\hline CADO LC10 & 25.7 & $\sim 0$ & 3.29 & 8.03 & 69.1 \\
\hline CADO LC11 & 47.5 & $\sim 0$ & 3.63 & 10.8 & 23.6 \\
\hline CADO LC17 & 36.7 & $\sim 0$ & 5.05 & 25.8 & 6.79 \\
\hline CADO LC20 & 23.2 & 0.506 & 10.3 & 25.9 & 86.2 \\
\hline CADO LC21 & 31.2 & $\sim 0$ & 8.22 & 23.2 & 72.7 \\
\hline CADO LC26 & 53.8 & $\sim 0$ & $\sim 0$ & 3.24 & 51.1 \\
\hline CADO LC41 & 29.0 & $\sim 0$ & 13.4 & 30.3 & 8.42 \\
\hline \multicolumn{6}{|c|}{ Squamous cell carcinoma } \\
\hline EBC-1 & 41.7 & $\sim 0$ & 1.96 & 9.06 & 127 \\
\hline LC-1 sq & 133 & $\sim 0$ & 8.72 & 23.2 & 110 \\
\hline $\mathrm{LK}-2$ & 109 & $\sim 0$ & 2.40 & 11.9 & 33.7 \\
\hline VMRC-LCP & 158 & $\sim 0$ & 3.58 & 16.8 & 153 \\
\hline CADO LC15 & 22.3 & 0.178 & 2.97 & 8.87 & 34.3 \\
\hline \multicolumn{6}{|c|}{ Large cell carcinoma } \\
\hline CADO LC1 & 9.31 & $\sim 0$ & 3.61 & 21.3 & 151 \\
\hline CADO LC3 & 29.2 & $\sim 0$ & $\sim 0$ & $\sim 0$ & 6.94 \\
\hline CADO LC24 & 148 & $\sim 0$ & 11.5 & 36.4 & 35.7 \\
\hline
\end{tabular}

a) Not determined. 

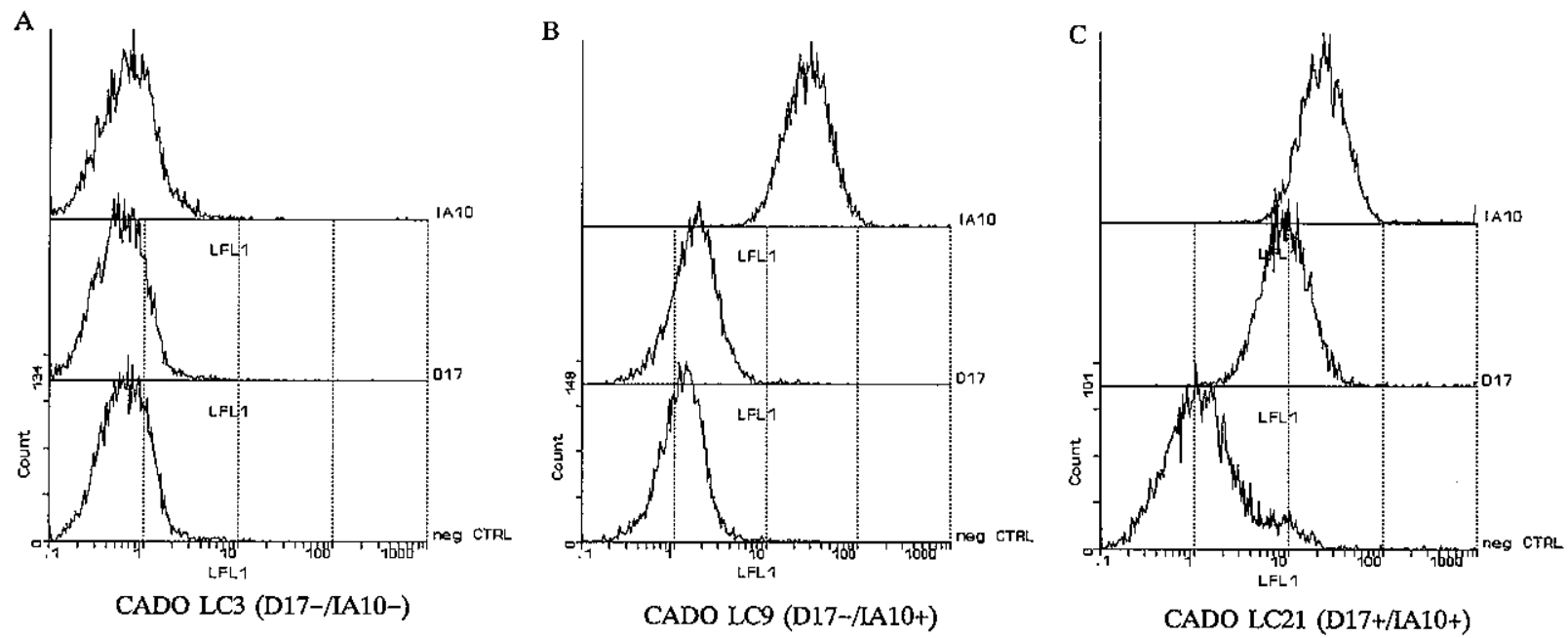

Fig. 1. Three patterns of DAF expression in lung cancer cells. Cells were treated with IA10 or D17, then FITC-labeled secondary $\mathrm{Ab}$, and analyzed by flow cytometry. Non-immune mouse IgG was used as a background control. A, CADO LC3 cells (large cell carcinoma) lack both IA10 and D17 epitopes. B, CADO LC9 cells (adenocarcinoma) express IA10 but not D17. C, CADO LC21 cells (adenocarcinoma) possess both IA10 and D17.
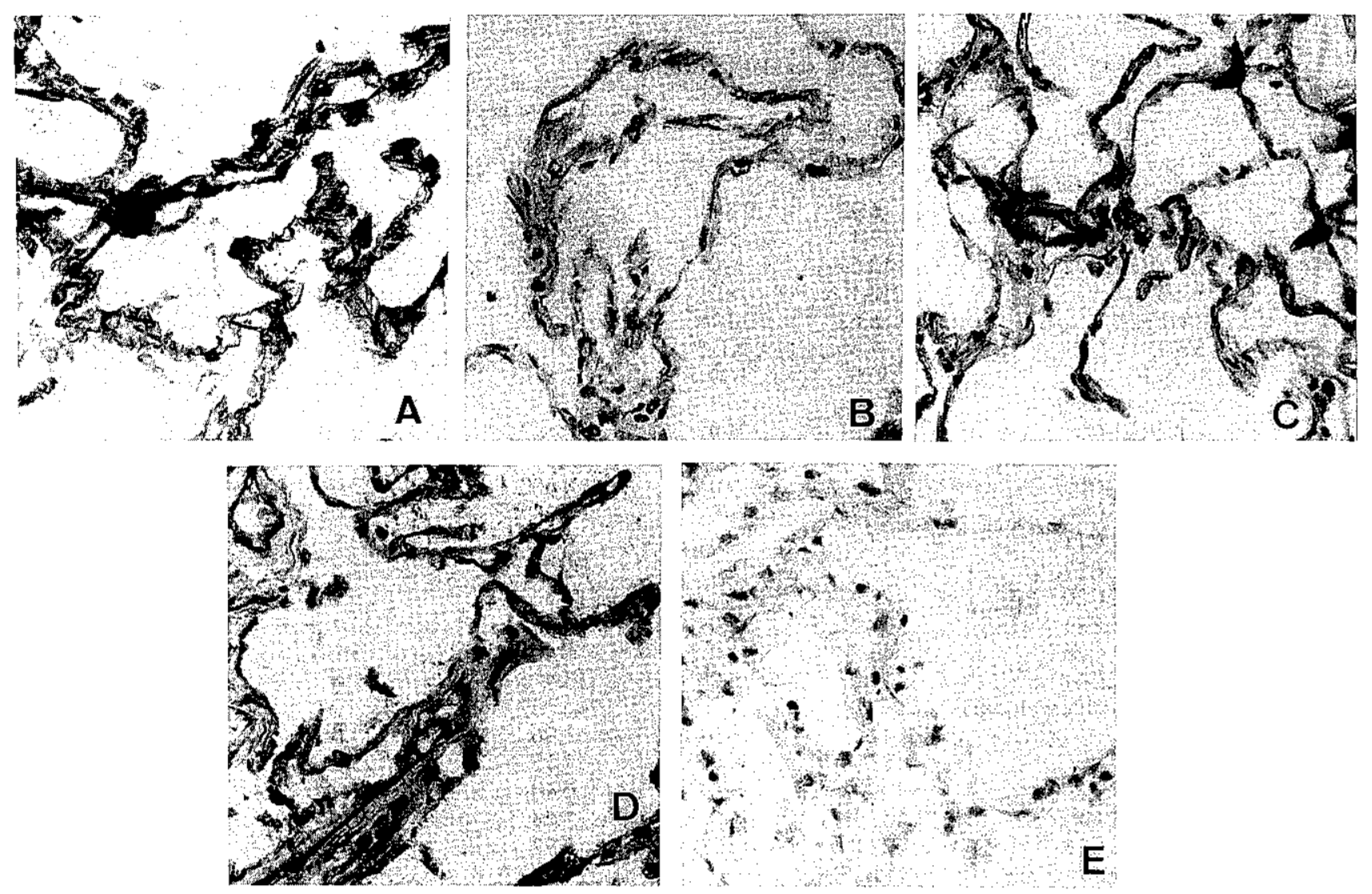

Fig. 2. Immunohistochemistry of complement-regulatory molecules in normal lung. The fixed lung specimens were stained with antibodies against DAF (IA10 and D17), MCP (M177), or CR1 (31R). A, DAF(IA10) and B, DAF(D17) were both expressed in pulmonary tissue, although the level of D17 was less than that of IA10. C, MCP and D, CD59 were detected but E, CR1 was not. 
A

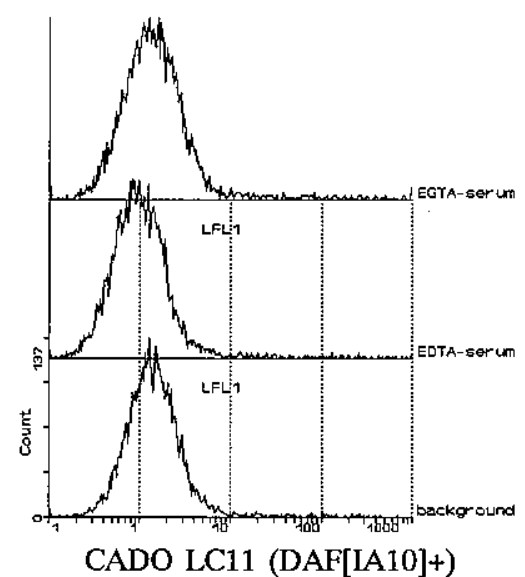

B

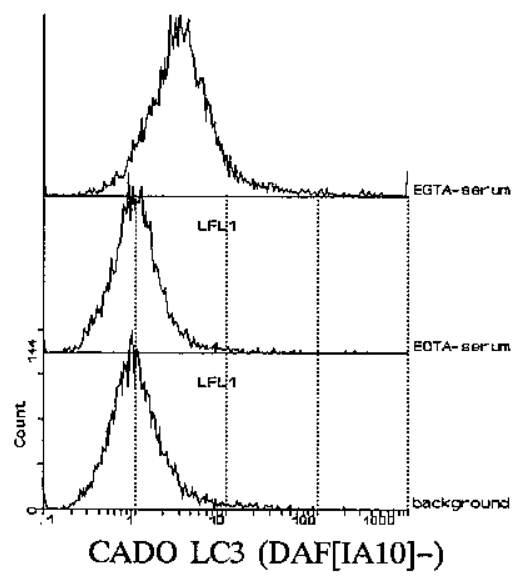

Fig. 3. Induction of homologous complement deposition on cancer cells. Cells were pretreated with M177 (MCP cofactor blocking $\mathrm{Ab}$ ), then treated with Mg-EGTA normal human serum or EDTA normal human serum, and the deposited C3 was assessed by flow cytometry using anti-C3c Ab. Non-immune mouse IgG was used as a background control. A, cell line expressing DAF showed no $\mathrm{C} 3$ deposition while B, cells without DAF allowed complement accumulation.

NSCLC were negative. All D17-positive cells expressed IA10. Only two carcinoma cell lines, CADO LC3 and SBC5, were completely devoid of DAF (IA10 $\left.{ }^{-} / \mathrm{D} 17^{-}\right)$. IA10 always yielded a greater fluorescent shift than D17, although the degree of the difference of MFS varied. Typical expression patterns of D17 and IA10 $\left(\mathrm{D} 17^{-} / \mathrm{IA} 10^{-}, \mathrm{D} 17^{-} / \mathrm{IA} 10^{+}\right.$, and $\left.\mathrm{D} 17^{+} / \mathrm{IA} 10^{+}\right)$are shown in Fig. 1.

Complement-regulatory molecules in normal pulmonary cells Normal pulmonary cells including alveolar, endothelial, and interstitial tissues expressed DAF (both IA10 and D17), MCP, and CD59. CR1 was not detected in normal lung cells (Fig. 2). Hence, the D17 epitope seems to be lost during the process of malignant transformation.

C3 deposition induced by Ab against MCP Examples of C3 fragment deposition on carcinoma cells are depicted in Fig. 3. A cell line with both D17 and IA10 expression (CADO LC11) refused to accept $\mathrm{C} 3$ deposition. A cell line of $\mathrm{D} 17^{-} / \mathrm{IA}^{+} 0^{+}$phenotype (CADO LC9) showed marginal $\mathrm{C} 3$ accumulation (data not shown), and one that lacks both epitopes (CADO LC3) displayed C3 accrual on the cell membrane.

\section{DISCUSSION}

As yet the expression of complement-regulatory proteins (CR1, DAF, MCP and CD59) in lung cancer has not been extensively investigated. The phenotype of the lung cancer cells was $\mathrm{CR} 1^{-} / \mathrm{MCP}^{+} / \mathrm{CD}^{2} 9^{+}$, regardless of histological subtypes. The high frequency of the
$\mathrm{CR}^{-} / \mathrm{MCP}^{+}$profile in lung cancer is consistent with previous reports suggesting that up-regulation of MCP concomitant with loss or down-regulation of CR1 is a characteristic phenotype of tumor cells. ${ }^{15,16)}$

Of considerable importance was the discrepancy observed between the reactivities of two mAbs against DAF. The D17 epitope was absent in $36.0 \%$ of the cell lines, whereas the IA10 epitope was detected in almost all cells. The disparity of reactivity was unique to DAF, since 3 anti-MCP and 3 anti-CR $1 \mathrm{mAbs}$ yielded similar fluorescence shifts to M177 and 31R, respectively (data not shown). Normal blood cells expressed both the D17 and the IA 10 epitopes, ${ }^{17)}$ as did normal pulmonary cells (Fig. 2). The discrepancy of reactivity of the anti-DAF $\mathrm{mAbs}$, therefore, was thought to be relevant to the malignant phenotype of these cells. To our knowledge, this is the first demonstration of a variant form of DAF in cancer cells.

DAF, like CD59, is a glycan phosphatidylinositol (GPI)-anchored protein, and is known to be deficient in paroxysmal nocturnal hemoglobinuria $(\mathrm{PNH})$, in which disorder of GPI-anchoring occurs. ${ }^{18)}$ The loss of reactivity to the D17 mAb was not considered to be owing to the aberrant GPI-anchoring, because most of the cells still expressed the IA10 epitope. Furthermore, another GPI-anchored protein, CD59, ${ }^{13)}$ was present in all cells including the D17-deficient cells.

We think that a possible mechanism for the discrepancy of the DAF epitopes in lung cancer cells is that the D17 epitope is structurally altered or made inaccessible, for example, being sterically hindered by other moieties 
or molecules. The IA10 epitope resides in the first short consensus repeat (SCR) of DAF, ${ }^{25)}$ whilst that of D17 is located in the vicinity of a serine/threonine-rich domain that is close to O-linked sugars. ${ }^{17)}$ Immunoblot analysis disclosed that O-glycanase treatment increased D17 reactivity for the DAF purified from erythrocytes (data not shown). Moreover, another $\mathrm{mAb} 1 \mathrm{C} 6$, which recognizes the third SCR, ${ }^{25)}$ showed similar results to IA 10 but not D17 (data not shown). Hence, the altered form of DAF is likely to originate from excessive glycosylation occurring in a malignant state. MCP also has large amounts of $\mathrm{O}$-linked sugars that modulate its function, ${ }^{21)}$ although the role of the O-linked sugars in DAF function is unknown. Of course, cDNA analysis of the DAF from these lung cancer cells would be needed before a final conclusion can be reached.

Complement (C3) deposition can be induced on cells with aberrant complement-regulatory proteins, ${ }^{15,24,26)}$ resulting in cell damage. To ascertain whether the lack of D17 epitope could be associated with C3-targeting, we incubated three types of cells, $\mathrm{IA} 0^{+} / \mathrm{D} 17^{+}, \mathrm{IA} 10^{+} /$ $\mathrm{D} 17^{-}$, and $\mathrm{IA} 10^{-} / \mathrm{D} 17^{-}$, with anti-MCP $\mathrm{mAb}$ to block MCP, followed by Mg-EGTA serum (Fig. 3). The degree of resultant $\mathrm{C} 3$ deposition was in the order of $\mathrm{IA} 10^{+} / \mathrm{D} 17^{+} \approx \mathrm{IA} 10^{+} / \mathrm{D} 17^{-}<\mathrm{IA} 10^{-} / \mathrm{D} 17^{-}$. The presence of D17 epitope seemed not to be essential to avoid complement attack.

\section{REFERENCES}

1) Parkin, D. M., Läärä, E. and Muir, C. S. Estimation of the worldwide frequency of sixteen major cancers in 1980. Int. J. Cancer, 41, 184-197 (1988).

2) Stanley, K. and Stjernswärd, J. Lung cancer - a worldwide health problem. Chest, 96, 1S-5S (1989).

3) Seifter, E. J. and Ihde, D. C. Small cell lung cancer: a distinct clinicopathologic entity. In "Lung Cancer. A Comprehensive Treatise," ed. J. D. Bitran, H. M. Golomb, A. G. Little and R. R. Weichselbaum, pp. 257-279 (1988). Grune \& Stratton, Orlando.

4) Fraser, R. G., Paré, J. A. P., Paré, P. D., Fraser, R. S. and Genereux, G. P. Neoplastic disease of the lung. In "Diagnosis of Diseases of the Chest," 3rd Ed., pp. 1327-1699 (1989). W. B. Saunders, Philadelphia.

5) Tateishi, R., Horai, T. and Hattori, S. Demonstration of argyrophil granules in small cell carcinoma of the lung. Virchows Arch. A. Pathol. Anat. Histol., 377, 203-210 (1978).

6) Gazdar, A. F. and Carney, D. N. Endocrine properties of small cell carcinoma of the lung. In "The Endocrine Lung in Health and Disease," ed. K. L. Becker and A. F. Gazdar, pp. 501-508 (1984). W. B. Saunders, Philadelphia.

7) Carney, D. N., Marangos, P. J., Ihde, D. C., Bunn, P. A., Jr., Cohen, M. H., Minna, J. D. and Gazdar, A. F. Serum
Cheung et al., using IA10 $\mathrm{mAb}$, have reported the absence of DAF in SCLC cells. ${ }^{8}$ NSCLC cells were not studied, however. In this study, CADO LC3 (large cell carcinoma) and probably SBC5 (small cell carcinoma) totally lacked DAF (IA $10^{-} / \mathrm{D} 17^{-}$). Two SCLC cell lines (CADO LC8 and Lu134A) were not reactive to D17 but were weakly IA10-positive. Our results thus showed that not only SCLC but also NSCLC cells can be DAF (IA10)-deficient. The levels of DAF are known to change during the course of viral infection ${ }^{27)}$ or under the influence of other reagents. ${ }^{28)}$ Although the origin of the variant DAF and its relation to histological subtypes in lung cancer is unclear at present, the variant form of DAF we found might be significant in relation to the pathogenesis of lung cancer.

\section{ACKNOWLEDGMENTS}

We are grateful to Dr. H. Akedo (Director, Center for Adult Diseases, Osaka) for invaluable discussions and to our colleagues, Miss A. Kojima, Drs. T. Horai, T. Matsuhisa, Ms. Y. Tanigaki, Mrs. Y. Saeki, Miss M. Kume, and Miss A. Itoh, for their assistance. This work was supported in part by Grants-inAid from the Ministry of Education, Science and Culture, and the Ministry of Health and Welfare of Japan (to Ts.S.).

(Received January 7, 1993/Accepted April 26, 1993)

neuron-specific enolase: a marker for disease extent and response to therapy of small-cell lung cancer. Lancet, i, 583-585 (1982).

8) Cheung, N-K. V., Walter, E. I., Smith-Mensah, W. H., Ratnoff, W. D., Tykocinski, M. L. and Medof, M. E. Decay-accelerating factor protects human tumor cells from complement-mediated cytotoxicity in vitro. J. Clin. Invest., 81, 1122-1128 (1988).

9) Fearon, D. T. Regulation of the amplification of C3 convertase of human complement by an inhibitory protein isolated from human erythrocyte membrane. Proc. Natl. Acad. Sci. USA, 76, 5867-5871 (1979).

10) Nicholson-Weller, A., Burge, J., Fearon, D. T., Weller, P. F. and Austen, K. F. Isolation of a human erythrocyte membrane glycoprotein with decay-accelerating activity for C3 convertases of the complement system. $J$. Immunol., 129, 184-189 (1982).

11) Seya, T., Turner, J. R. and Atkinson, J. P. Purification and characterization of a membrane protein (gp45-70) that is a cofactor for cleavage of $\mathrm{C} 3 \mathrm{~b}$ and C4b. J. Exp. Med., 163, 837-855 (1986).

12) Sugita, Y., Nakano, Y. and Tomita, M. Isolation from human erythrocytes of a new membrane protein which inhibits the formation of complement transmembrane 
channels. J. Biochem., 104, 633-637 (1988).

13) Okada, N., Harada, R., Fujita, T. and Okada, H. A novel membrane glycoprotein capable of inhibiting membrane attack by homologous complement. Int. Immunol., 1, 205208 (1989).

14) Matsumoto, T., Terasaki, T., Mukai, K., Wada, M., Okamoto, A., Yokota, J., Yamaguchi, K., Kato, K., Nagatsu, T. and Shimosato, Y. Relation between nucleolar size and growth characteristics in small cell lung cancer cell lines. Jpn. J. Cancer Res., 82, 820-828 (1991).

15) Seya, T., Hara, T., Matsumoto, M. and Akedo, H. Quantitative analysis of membrane cofactor protein (MCP) of complement. High expression of MCP on human leukernia cell lines, which is down-regulated during cell differentiation. J. Immunol., 145, 238-245 (1990).

16) Hara, T., Kojima, A., Fukuda, H., Masaoka, T., Fukumori, Y., Matsumoto, M. and Seya, T. Levels of complement regulatory proteins, CD35 (CR1), CD46 (MCP) and CD55 (DAF) in human haematological malignancies. Br. J. Haematol., 82, 368-373 (1992).

17) Hara, T., Matsumoto, M., Fukumori, Y., Miyagawa, S., Hatanaka, M., Kinoshita, T., Seya, T. and Akedo, H. A monoclonal antibody against human decay-accelerating factor (DAF, CD55), D17, which lacks the reactivity with semen DAF. Immunol, Lett. (1993), in press.

18) Kinoshita, T., Medof, M. E., Silber, R. and Nussenzweig, V. Distribution of decay-accelerating factor in the peripheral blood of normal individuals and patients with paroxysmal nocturnal hemoglobinuria. J. Exp. Med., 162, 75-92 (1985).

19) Sugita, Y., Choi, N., Tobe, T., Tomita, M. and Mazda, T. Some features of MACIF, a new regulatory protein of complement cascade. Proc. Jpn. Soc. Immunol., 19, 264 (1989).

20) Seya, T., Inoue, H., Okada, M., Matsumoto, M., Kitamura, H., Kinoshita, T. and Akedo, H. Proteolytic elimination of decay-accelerating factor (DAF): lytic ab- normality coincides with removal of DAF in papaintreated human erythrocytes. Mol. Immunol., 27, 69-78 (1990).

21) Matsumoto, M., Seya, T. and Nagasawa, S. Polymorphism and proteolytic fragments of granulocyte membrane cofactor protein (MCP, CD46) of complement. Biochem. J., 281, 493-499 (1992).

22) Ripoche, J. and Sim, R. B. Loss of complement receptor type 1 (CR1) on ageing of erythrocytes. Studies of proteolytic release of the receptor. Biochem. J., 235, 815-821 (1986).

23) Sayama, K., Shiraishi, S., Shirakata, Y., Kobayashi, Y., Seya, T. and Miki, Y. Expression and characterization of membrane co-factor protein (MCP) in human skin. $J$. Invest. Dermatol., 97, 722-724 (1991).

24) Seya, T., Hara, T., Matsumoto, M., Sugita, Y. and Akedo, H. Complement-mediated tumor cell damage induced by antibodies against membrane cofactor protein (MCP, CD46). J. Exp. Med., 172, 1673-1680 (1990).

25) Lublin, D. M., Kinoshita, T., Fujita, T., Austee, D. J. and Rosse, W. F. Mapping of epitopes, glycosylation sites, and functional domains in human decay-accelerating factor. Complement Inflammation, 8, 184 (1991).

26) Okada, H., Tanaka, H. and Okada, N. Prevention of complement activation on the homologous cell membrane of nucleated cells as well as erythrocytes. Eur. J. Immunol., 13, 340-345 (1983).

27) Lederman, M. M., Purvis, S. F., Walter, E. I., Carey, J. T. and Medof, M. E. Heightened complement sensitivity of acquired immunodeficiency syndrome lymphocytes related to diminished expression of decay-accelerating factor. Proc. Natl. Acad. Sci. USA, 86, 4205-4209 (1989).

28) Bryant, R. W., Granzow, C. A., Siegel, M. I., Egan, R. W. and Morassium, B. M. Wheat germ agglutinin and other selected lectins increase synthesis of decay-accelerating factor in human endothelial cells. J. Immunol., 147, 18561861 (1991). 